\title{
Deep resistivity "turnover" effect at oil generation "peak" in the Woodford Shale, Anadarko Basin, USA
}

\author{
Ting Wang ${ }^{1,2,4,5} \cdot$ Jacobi David ${ }^{3}$
}

Received: 1 September 2018 / Published online: 5 October 2019

(c) The Author(s) 2019

\begin{abstract}
The Devonian Woodford Shale in the Anadarko Basin is a highly organic, hydrocarbon source rock. Accurate values of vitrinite reflectance $\left(R_{\mathrm{o}}\right)$ present in the Woodford Shale penetrated by 52 control wells were measured directly. These vitrinite reflectance values, when plotted against borehole resistivity for the middle member of the Woodford Shale in the wells, display a rarely reported finding that deep resistivity readings decrease as $R_{\mathrm{o}}$ increases when $R_{\mathrm{o}}$ is greater than $0.90 \%$. This phenomenon may be attributed to that aromatic and resin compounds containing conjugated pi bonds generated within source rocks are more electrically conductive than aliphatic compounds. And aromatic and resin fractions were generated more than aliphatic fraction when source rock maturity further increases beyond oil peak. The finding of the relationship between deep resistivity and $R_{\mathrm{o}}$ may re-investigate the previously found linear relationship between source rock formation and aid to unconventional play exploration.
\end{abstract}

Keywords Resistivity $\log \cdot$ Source rock thermal maturity $\cdot$ Vitrinite reflectance $\cdot$ Woodford Shale

\section{Introduction}

In a lot of early-stage unconventional shale play explorations, several key geochemical parameters, including organic richness (TOC) and thermal maturity, are need to be known to evaluate potential unconventional shale play (Comer 2005; Jarvie 2011). This study focuses on hydrocarbon source rock thermal maturity, which is scaled by vitrinite reflectance $\left(R_{\mathrm{O}}\right)$ in practice. It is particularly significant to

Edited by Jie Hao

Ting Wang

tingwang@ou.edu

1 College of Resources and Environment, Yangtze University, Wuhan 430100, China

2 School of Geology and Geophysics, University of Oklahoma, Norman, OK 73019, USA

3 ConocoPhillips Company, Houston 77079, USA

4 State Key Laboratory of Petroleum Resources and Prospecting, China University of Petroleum, Beijing 102249, China

5 Key Laboratory of Exploration Technology for Oil and Gas Research (Yangtze University), Ministry of Education, Wuhan 430100, China map those potential shale play targets' organic matter thermal maturity in 3-D geological framework if to target at shale oil, because the most appropriate maturity range of many successful shale oil plays is centered on $0.90 \% R_{\mathrm{o}}$ based on the successful cases of shale oil plays in North America (Comer 2005; Slatt et al. 2009a; Jarvie 2011). The reason behind these successful experiences would be source beds' maturity control hydrocarbon phase and mobility. In other words, organic maturity drives the success of shale oil play to some extent. But in most cases, cost of the analysis and insufficient well cuttings or cores generally restrict the interpretation of a basin's maturity to the contouring of a relatively small number of vitrinite reflectance values over a large area. Another successful experience from the shale oil "boom" in North America is that the economically profitable shale oil "target" is usually the "old" source rock beds of the conventional petroleum systems (Loucks and Ruppel 2007; Singh 2008; Comer 2008; Slatt et al. 2009a, b). The Woodford Shale of Late Devonian to Early Mississippian age is a typical resource play target of these types of shale plays. It has not only proven to be an excellent source rock, charging the conventional reservoirs in Kansas and Oklahoma (Comer and Hinch 1987; Burruss and Hatch 1989; Philp et al. 1989; Jones and Philp 1990; Comer 1991b; Wang 1993; Wang and Philp 1997), but also become a frontier for unconventional 
Table 1 Well list and the corresponding middle Woodford member average measured $R_{\mathrm{o}}$ value used in this study

\begin{tabular}{|c|c|c|c|c|c|}
\hline Code & Well name & API & $X, \mathrm{~m}$ & $Y, \mathrm{~m}$ & $\begin{array}{l}\text { M-WF Ave. } R_{\mathrm{o}} \\
\text { (measured) }{ }^{\mathrm{a}}, \%\end{array}$ \\
\hline 1 & DUGGER 1-18 & 35039203660000 & $466,289.69$ & $3,939,717.99$ & 4.89 \\
\hline 2 & GREEN 1-3 & 35009205660000 & $424,834.4$ & $3,914,727.14$ & 4.05 \\
\hline 3 & ROBINSON 1-1 & 35009204260000 & $456,480.73$ & $3,904,043.43$ & 3.88 \\
\hline 4 & BOWERS C-1 & 42211600490000 & $402,238.36$ & $3,949,712.11$ & 3.40 \\
\hline 5 & HEFLEY 1-A-90 & 42211200810000 & $388,452.15$ & $3,949,280.99$ & 3.29 \\
\hline 6 & MATHERS RANCH \#5 & 42211300880000 & $389,109.86$ & $3,974,217.27$ & 3.10 \\
\hline 7 & REED J R 1-31 & 42483300850000 & $392,937.09$ & $3,928,998.14$ & 3.03 \\
\hline 8 & ALPHA JONES 1 & 35009202930000 & $450,419.8$ & $3,901,664.78$ & 2.61 \\
\hline 9 & SWITZER G 2 & 35129211580000 & $459,264.25$ & $3,963,606.24$ & 2.59 \\
\hline 10 & MCKAY 1 & 35129207530000 & $458,034.69$ & $3,974,614.56$ & 2.48 \\
\hline 11 & BOBWHITE UNIT 1 & 35149200230000 & $509,682.52$ & $3,891,207.08$ & 2.03 \\
\hline 12 & WILBUR HAYES 1-27 & 35039200550000 & $530,293.56$ & $3,926,352.74$ & 2.00 \\
\hline 13 & FRIEDA $1-25$ & 35011215000000 & $541,836.05$ & $3,936,910.96$ & 1.89 \\
\hline 14 & MILDRED DAVIDSON 1 & 42483300110000 & $401,833.11$ & $3,912,643.98$ & 1.87 \\
\hline 15 & GRAHAM 191 & 35051210280000 & $593,914.87$ & $3,842,447.95$ & 1.86 \\
\hline 16 & CUPP B-3 & 35009207790000 & $412,756.15$ & $3,910,031.39$ & 1.82 \\
\hline 17 & TROY SMITH H 1 & 35015000070000 & $561,593.39$ & $3,922,308.75$ & 1.61 \\
\hline 18 & MIAMI CATTLE 1 & 42211000730000 & $363,698.8$ & $3,949,950.12$ & 1.56 \\
\hline 19 & HOWLING WOMAN 1-12 & 35011218550000 & $552,106.29$ & $3,941,530.07$ & 1.55 \\
\hline 20 & RICHARDSON 8-1 & 35051208490000 & $584,150.22$ & $3,912,312.29$ & 1.46 \\
\hline 21 & ESCO HANAN 1-26 & 35045208760000 & $443,925.79$ & $4,004,367.29$ & 1.42 \\
\hline 22 & SABINE 1 & 35043211020000 & $483,650.64$ & $3,980,957.11$ & 1.36 \\
\hline 23 & WARD 1-28 & 35017222670000 & $566,576.87$ & $3,946,683.04$ & 1.32 \\
\hline 24 & HORN A 1 & 42483000770000 & $375,625.74$ & $3,936,521.56$ & 1.27 \\
\hline 25 & KRUGER 1-6 & 35039209200000 & $515,058.03$ & $3,953,027.81$ & 1.26 \\
\hline 26 & SCHAFER 1 & 35051212000000 & $595,874.42$ & $3,896,528.49$ & 1.16 \\
\hline 27 & SCHREINER 1-2 & 35011222620000 & $549,065.54$ & $3,980,894.68$ & 1.15 \\
\hline 28 & HECKES 1 & 35017222740000 & $584,154.31$ & $3,932,574.46$ & 1.14 \\
\hline 29 & HUSSEY-REYNOLDS 1-11 & 35137236510000 & $618,992.72$ & $3,835,213.29$ & 1.07 \\
\hline 30 & WALTERS 1-13 & 35043211320000 & $522,781.05$ & $3,997,015.1$ & 1.05 \\
\hline 31 & IRENE BURGESS 1-20 & 35043211330000 & $497,336.56$ & $3,995,278.88$ & 1.02 \\
\hline 32 & REHL 2-12 & 35011217420000 & $541,127.93$ & $3,998,667.14$ & 0.94 \\
\hline 33 & DUPIRE 1 & 35051216490000 & $616,288.79$ & $3,856,072.06$ & 0.90 \\
\hline 34 & WILSON 18-1 & 35153205550000 & $446,292.61$ & $4,046,201.03$ & 0.89 \\
\hline 35 & MAINKA-RING UNIT 1 & 35051001160000 & $621,276.85$ & $3,865,023.67$ & 0.88 \\
\hline 36 & MATLI/A/1 & 35011215010000 & $565,591.38$ & $3,969,972.59$ & 0.88 \\
\hline 37 & GOOD 1 & 35051212140000 & $617,738.55$ & $3,872,937.07$ & 0.83 \\
\hline 38 & GARRETT 2 & 35073215970000 & $586,250.2$ & $3,976,611.71$ & 0.78 \\
\hline 39 & SHIELDS 1-1 & 35049226840000 & $629,994.4$ & $3,856,318.28$ & 0.75 \\
\hline 40 & HILL 1-1 & 35051216710000 & $610,899.44$ & $3,905,364.44$ & 0.73 \\
\hline 41 & ROETZEL UNIT B 1 & 35011300360000 & $570,492.89$ & $3,997,481.35$ & 0.71 \\
\hline 42 & EUGENE 1-24 & 35073227420000 & $579,705.94$ & $3,996,340.26$ & 0.66 \\
\hline 43 & CRAIG 1-7 & 35087213770000 & $631,980.75$ & $3,874,546.48$ & 0.64 \\
\hline 44 & $\mathrm{BANE} / \mathrm{B} / 2$ & 35093219230000 & $519,753.85$ & $4,031,325.7$ & 0.63 \\
\hline 45 & ST-HENNESSY-UN-102 1 & 35073204290000 & $594,157.57$ & $3,988,949.36$ & 0.58 \\
\hline 46 & DOANE $1-22$ & 35093219870000 & $575,750.29$ & $4,025,211.95$ & 0.56 \\
\hline 47 & WEST EDMOND SWD 1-24 & 35017239980000 & $619,344.37$ & $3,947,880.21$ & 0.55 \\
\hline 48 & DANNEHL 2-16 & 35017204490000 & $604,439.66$ & $3,940,609.93$ & 0.54 \\
\hline 49 & HENDERSON 1 & 35017203740000 & $612,935.55$ & $3,923,838.96$ & 0.53 \\
\hline 50 & BLOYD 2 & 35151201560000 & $515,644.06$ & $4,073,437.34$ & 0.52 \\
\hline 51 & RUTH 1 & 35073209590000 & $616,741.23$ & $3,962,759.77$ & 0.37 \\
\hline 52 & ROBBERSON 10-1 & 35017202280000 & $617,432.82$ & $3,913,731.22$ & 0.32 \\
\hline
\end{tabular}


Table 1 (continued)

${ }^{a}$ M-WF: middle Woodford member; M-WF Ave. $R_{\mathrm{o}}$ (measured) \% denotes average measured vitrinite reflectance value of the middle Woodford member section

resource play exploration and production (Cardott 2014; Kvale and Bynum 2014). The unconventional Woodford resource play in Oklahoma encompasses four regions, namely Anadarko-Woodford, Arkoma-Woodford, NemahaWoodford and Southern Oklahoma-Woodford, and has been estimated to contain $0.24 \times 10^{12} \mathrm{ft}^{3}\left(6.8 \times 10^{9} \mathrm{~m}^{3}\right)$ of natural gas and $70 \times 10^{9} \mathrm{bbl}\left(11 \times 10^{9}\right.$ ton $)$ of oil, in place and potentially producible, on the basis of mass balance calculations, indicating a huge potential as an unconventional hydrocarbon production target (Comer 2005). In general, well control is better than seismic data control in terms of vertical formation resolution. Therefore, to predict key geochemical parameters, especially organic richness and maturity, from wireline logs is of practical significance from the perspective of unconventional shale play exploration. In other words, it is necessary to revisit "old" well logs to assess several key geochemical parameters based on the "old" well logs.

The endeavor to look for a relationship between wireline $\operatorname{logs}$ and geochemical parameters if any and apply that relationship to predict geochemical parameters without measuring core data but simply based on wireline logs has been years (Meissner 1978; Smagala et al. 1984; Zhao et al. 2007; Passey et al. 2010). Meissner (1978) noticed that the Bakken Shale in the mature areas of the Williston Basin had much higher resistivity than in the immature areas. This was also noticed by Goff (1983) working with the Kimmeridge Clay in the northern North Sea of the UK. Meyer and Nederlof (1986) to some extent combined the observations of the above researchers by producing density versus resistivity (and sonic versus resistivity) cross-plots in order to separate source rocks from non-source rocks on a global scale. Smagala et al. (1984) found a linear relationship between resistivity and $R_{\mathrm{o}}$ that allowed the mapping of organic maturation levels over a large part of the marine siliciclastic basin through the use of a large number of available electric logs. Passey et al. (2010) reported that in some shale-gas reservoirs that are at very high maturities $\left(R_{\mathrm{o}}>3\right)$, the overall rock resistivity can be 1-2 orders of magnitude less than that is observed in the same formation at lower thermal maturities ( $R_{\mathrm{o}}$ between 1 and 3 ) perhaps because the carbon in the organic matter is recrystallizing to a precursor of mineral graphite, which is electrically conductive. The work reported hereby was a "by-product" of the research which initially aims to derive quantitative relationships between wireline logs and geochemical parameters if any and to develop a scheme for calculation of source rock richness and maturity from wireline logs which can be applied on a "global" basis. Here, we display a rarely reported finding that deep resistivity readings decrease as $R_{\mathrm{o}}$ increases when $R_{\mathrm{o}}$ is over $0.90 \%$. The new findings on the relationship between deep resistivity and $R_{\mathrm{o}}$ may re-investigate the previously found linear relationship between resistivity and $R_{\mathrm{o}}$ of source rock formation.

\section{Data sets and methodology}

\subsection{Geological settings of study area and data sets}

The Woodford Shale of Late Devonian to Early Mississippian age is an organic-rich black shale widely distributed over the southern Midcontinent from the Iowa Basin in Kansas to the Permian Basin in West Texas (Comer and Hinch 1987; Comer 1991b). It was found to be distributed in most of Oklahoma, including the Anadarko Basin, the Anadarko Shelf, Cherokee Platform and the Arkoma Basin. In the early Paleozoic time, three major tectonic/depositional provinces existed in Oklahoma: the Oklahoma Basin, the southern Oklahoma Aulacogen and the Ouachita Trough. The Oklahoma Basin, initially formed during the continental breakup in the Late Precambrian (Miall 2008), was a shelflike area that received widespread and thick shallow-marine carbonates interbedded with thin marine shale and sandstones (Johnson 1989; Northcutt et al. 2001). The southern Oklahoma Aulacogen, a west-northwest-trending trough derived from one of the failed rifts during the breakup of the supercontinent Rodinia (Miall 2008), was the depocenter for the Oklahoma Basin and the precursor of the Anadarko Basin (Johnson 1989; Northcutt et al. 2001). The Ouachita Trough received deep-water sediments deposited along a rift located in the southern margin of the North American craton (Johnson 1989; Northcutt et al. 2001). From Silurian to Middle Devonian clean-washed skeletal limestone, argillaceous and silty carbonates, referred to as the Hunton Group in Oklahoma, were deposited in a shallow marine setting (Northcutt et al. 2001). Epeirogenic uplifts interrupted deposition, resulting in two regional unconformities. One unconformity arose during pre-middle Early Devonian (preFrisco-Sallisaw unconformity) and the second one during pre-Late Devonian (pre-Woodford-Chattanooga unconformity; Johnson 1989). In southern Oklahoma, the pre-Woodford-Chattanooga unconformity eroded to the Upper Ordovician, and in northern Oklahoma, the erosion sculpted out Upper Cambrian-Lower Ordovician rocks (Kirkland et al. 1992). 


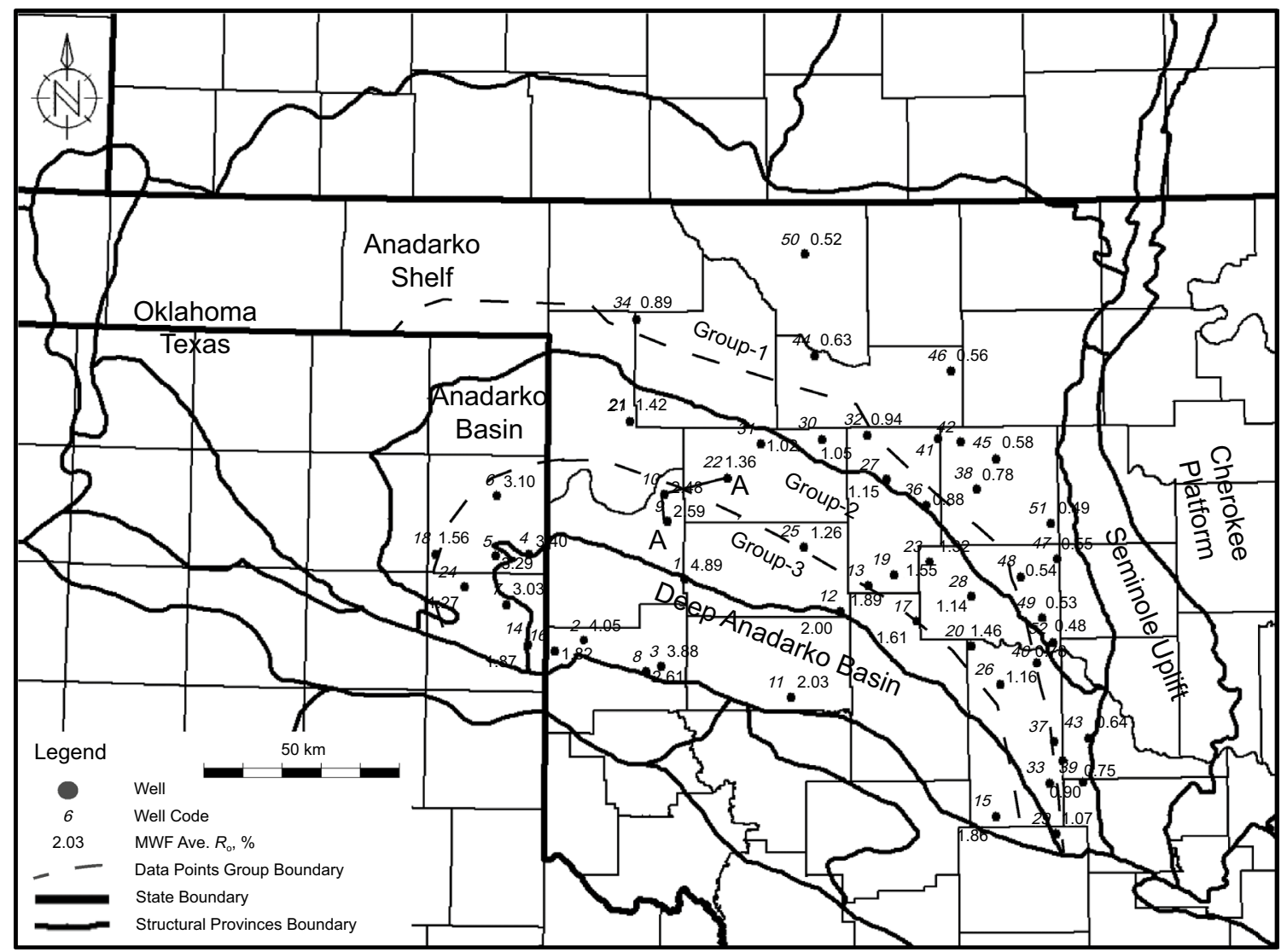

Fig. 1 Structural province map of the Anadarko Basin showing locations of the Woodford Shale rock samples analyzed in this study (well names in Table 1); $A-A^{\prime}$ cross section is to display the representative log characteristics of three Woodford members (log characteristics shown in Fig. 2); "MWF Ave. $R_{\mathrm{o}}$ " represents "Average $R_{\mathrm{o}}$ value of the middle Woodford member"; data points are classified into three groups whose geographic location is separated by dashed lines

The Woodford Formation in the Anadarko Basin was thought to be deposited in a restricted basin developed in an epeiric sea within the passive margin (Amsden 1975; Wang and Philp 1997; Kim and Philp 2000; Blakey 2008; Comer 2008; Haq and Schutter 2008; Miall 2008). On the Cherokee Platform, the Woodford Shale was deposited on a major regional unconformity developed during the Late Devonian (Amsden 1975). It is conformably overlain by limestone and shale of Early Mississippian age (Fig. 2). The predominant lithology of the Woodford Shale is black shale. Other common lithologies include chert, siltstone, sandstone, dolostone and light-colored shale (Amsden 1967; Amsden 1975; Comer 1991b). A typical core from the Woodford can contain 30\%-50\% quartz, $0 \%-20 \%$ calcite/dolomite, $0 \%-20 \%$ pyrite and $10 \%-50 \%$ total clay, a variance in mineralogy that occurs on a regional scale and within the stratigraphic section. These differences can have an effect on the porosity and permeability of the interval as they are reported to range from $3 \%$ to $9 \%$ and 100 nd-0.001 md, respectively (Comer 1991a, b).
A number of Woodford core samples from 52 wells and corresponding wireline logs (GR, SP, resistivity, density, etc.) provided by ConocoPhillips were collected for this study (well location shown in Fig. 1). Accurate values of vitrinite reflectance $\left(R_{\mathrm{o}}\right)$ present in the Woodford Shale penetrated by 52 control wells were measured directly. The specific details concerning analytical techniques are summarized in Sect. 2.2.

\subsection{Analytical Methods}

Woodford Shale section was identified and subdivided into three informal stratigraphic members: upper, middle and lower Woodford members (Amsden 1975; Slatt et al. 2009a) from GR, SP, RHOB (density log) and deep resistivity logs based on the Woodford electronic log characteristics in the study area (Hester et al. 1988, 1990). The middle Woodford member rock samples were initially screened by determining their total organic carbon (TOC) and Rock-Eval parameters. The organic-rich samples were subjected to vitrinite reflectance $\left(R_{\mathrm{o}}\right)$ measurements. Measured vitrinite reflectance 
$A^{\prime}$

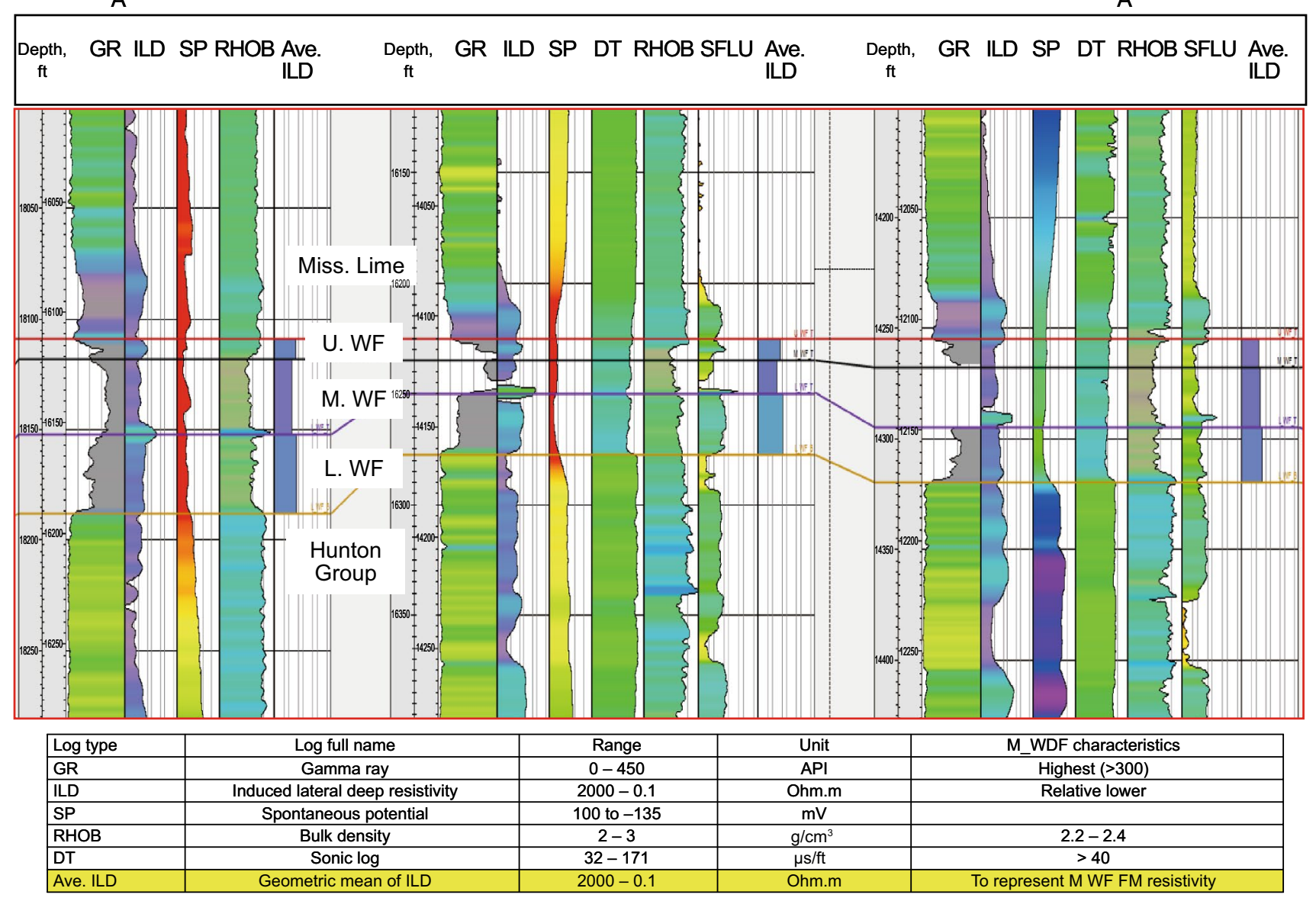

Fig. 2 Woodford Shale stratigraphic subdivision with well logs ( $U$. WF upper Woodford, $M$. WF middle Woodford, $L$. WF lower Woodford, Miss. Lime Mississippian limestone); the location of $A-A^{\prime}$ cross section is shown in Fig. 1

$\left(R_{\mathrm{o}}\right)$ values from all of the Woodford cores were obtained from the organic petrographic pellets (either made from a whole rock or a kerogen concentrate if it is not easy to look for good vitrinite from a whole rock) prepared at the Oklahoma Geological Survey Organic Petrography Laboratories in Norman, Oklahoma, and measured at the University of Oklahoma Organic Geochemistry Laboratories by the author of this study. Wireline logs were provided by Mr. David Jacobi from the Geology \& Geophysics \& Reservoir Engineering Department of ConocoPhillips Company, Houston. Wireline logs were loaded onto Schlumberger Petrel and treated to calculate geometric average deep induction log (ILD) values for the middle Woodford member (M-WF) for each well.

\section{Results and discussion}

Figure 2 is a typical well-log cross section showing clearly three informal stratigraphic Woodford members which are highly correlative and consistent over virtually the entire
Anadarko Basin. The middle Woodford member has the higher TOC values (Miceli 2010; Miceli and Philp 2012; Wang 2016; Wang and Philp 2019) than the upper and lower Woodford members, resulting in its diagnostic well log features including: (1) relatively lower deep ILD resistivity compared with upper and lower members; (2) lower bulk density $\left(2.2-2.4 \mathrm{~g} / \mathrm{cm}^{3}\right)$; (3) lower SP; (4) shorter DT (sonic log) reading; and (5) extremely high GR (over 300 API) (Hester et al. 1988, 1990). Pristane and phytane $(\mathrm{Pr} / \mathrm{Ph})$ and biomarker ratios suggest the establishment of stronger anoxic conditions during deposition of the middle Woodford member than the upper Woodford member, where the latter may have received an additional siliciclastic organic matter input (Miceli and Philp 2012; Wang 2016; Wang and Philp 2019). In the Cherokee Platform in the proximity of the Nemaha Uplift, $\mathrm{Pr} / \mathrm{Ph}$ ratios indicate deposition under suboxic to dysoxic conditions for the Woodford Shale interval analyzed (Wang 2016; Wang and Philp 2019). Based on these previous studies, the middle Woodford member was used to represent the whole Woodford section in this study. 


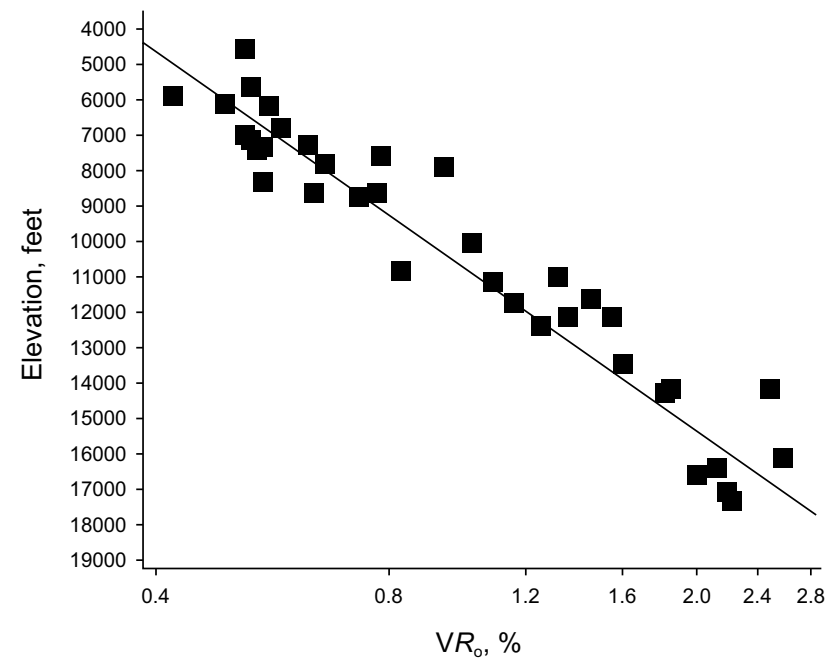

Fig. 3 Relationship between depths and vitrinite reflectance $\left(R_{\mathrm{o}}\right)$ of the middle Woodford member in the Anadarko Basin

By cross-plotting sample depth versus corresponding vitrinite reflectance $\left(R_{\mathrm{o}}\right)$ values, middle Woodford member rock samples from the studied wells in the Anadarko Basin (Fig. 3) show a very good linear relationship between measured depth and $R_{\mathrm{o}}$ values (in logarithm scale). This finding is consistent with that found on the Niobrara " $K$ " zone organicrich calcareous shale by Smagala et al. (1984). Lockridge and Scholle (1978) noticed a reduction in porosity with increased burial depth for the Niobrara chalks in the Denver Basin. Smagala et al. (1984) attributed the co-increases in resistivity of the chalk with burial depth to the consequence of the porosity reduction with increased overburden according to the empirical Archie equation (Archie, 1942). This finding is consistent with that the Woodford section in the Anadarko Basin was undertaking a "simple" burial history without multiple stages of subsiding and uplifting (Amsden 1975; Johnson 1989; Hester et al. 1988, 1990; Comer 1991b, 2005, 2008), which may lead to that both the burial depth and vitrinite reflectance "recorded" the thermal stress applied on the rock (Pepper and Corvi 1995). In Fig. 4, the starting point for the Woodford Shale entering early oil window in the Anadarko Basin is around $35 \Omega \mathrm{m}$, which is consistent with that reported by Schmoker and Hester (1990). The reason may be attributed to that there are many uncertainties in terms of relationship between resistivity and thermal maturity during the stage in which the source rock had not yet entered the oil window (Schmoker and Hester 1990). By plotting average formation resistivity readings of the middle Woodford member (geometric average value of ILD log readings of the middle Woodford member used in this study) versus average $R_{\mathrm{o}}$ value of the corresponding middle Woodford member, it was shown that formation resistivity increases as maturity increases before the

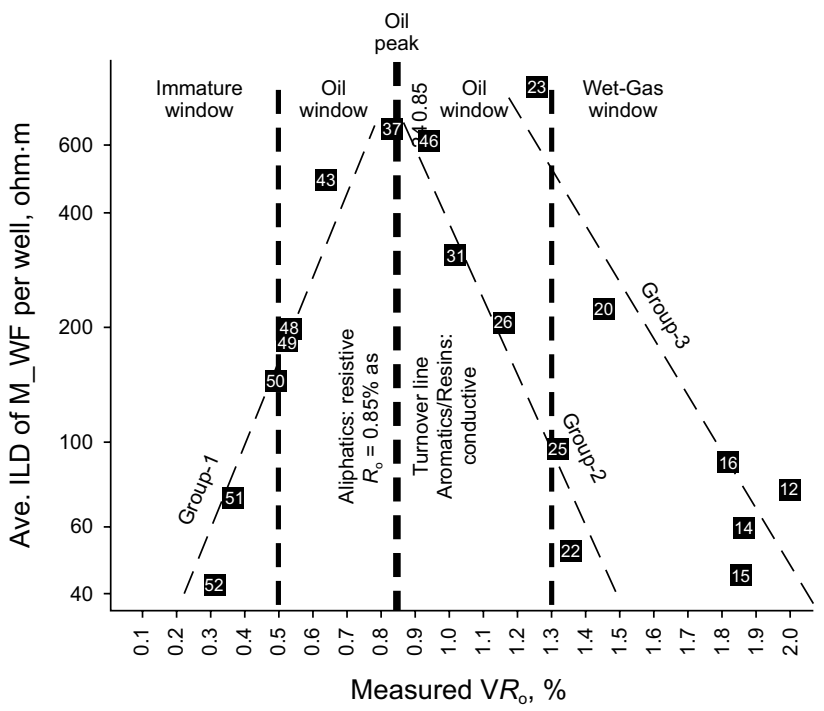

Fig. 4 Relationship between the middle Woodford member resistivity and vitrinite reflectance $\left(R_{\mathrm{o}}\right)$ of the studied wells in the Anadarko Basin; numbers within the data points are well codes in Table 1

oil generation peak $\left(R_{\mathrm{o}} \sim 0.85 \%\right)$ and decreases as maturity further increases beyond the oil generation peak.

The resistivity of a rock is directly related to those components that are electrically conductive. In conventional reservoirs, formation water, usually thought to allow for ionic conduction, is the primary conductor of electricity. Low resistivity is observed when the amount of saline water filled in porosity is high - the larger the volume of formation water, the lower the resistivity of the fluid-filled rock. From the perspective of traditional reservoir petrophysics, which did not treat too much organic-rich components like kerogen, hydrocarbon fluids (oil or gas) are non-conductive, and when they are present in sufficient quantities, they displace the amount of formation water, resulting in resistivity values higher than the same rock fully filled with electrically conductive formation water (Archie 1942). There are many variants to the interpretation of resistivity in conventional reservoirs (e.g., clay conductivity and shaly sand analysis; thin-bed effects due to interbedded shale; Waxman and Smits 1968; Worthington 1985; Passey et al. 2006), but these are beyond the scope of the current paper. Based on previous consideration, a model was proposed to interpret the finding in this study. As source rock enters "oil window" approaching "oil peak" ( $R_{\mathrm{o}}$ less than $\left.0.85 \%\right)$, it is generating greater amount of aliphatic compounds than aromatic and resin fractions. Aliphatic compounds are less conductive than aromatic and resin fractions since the latter contain a larger number of conjugated $\pi$-bonds, which allow delocalized electrons to flow through the $\pi$-bonds. However, as source rock maturity further increases beyond oil peak, it 


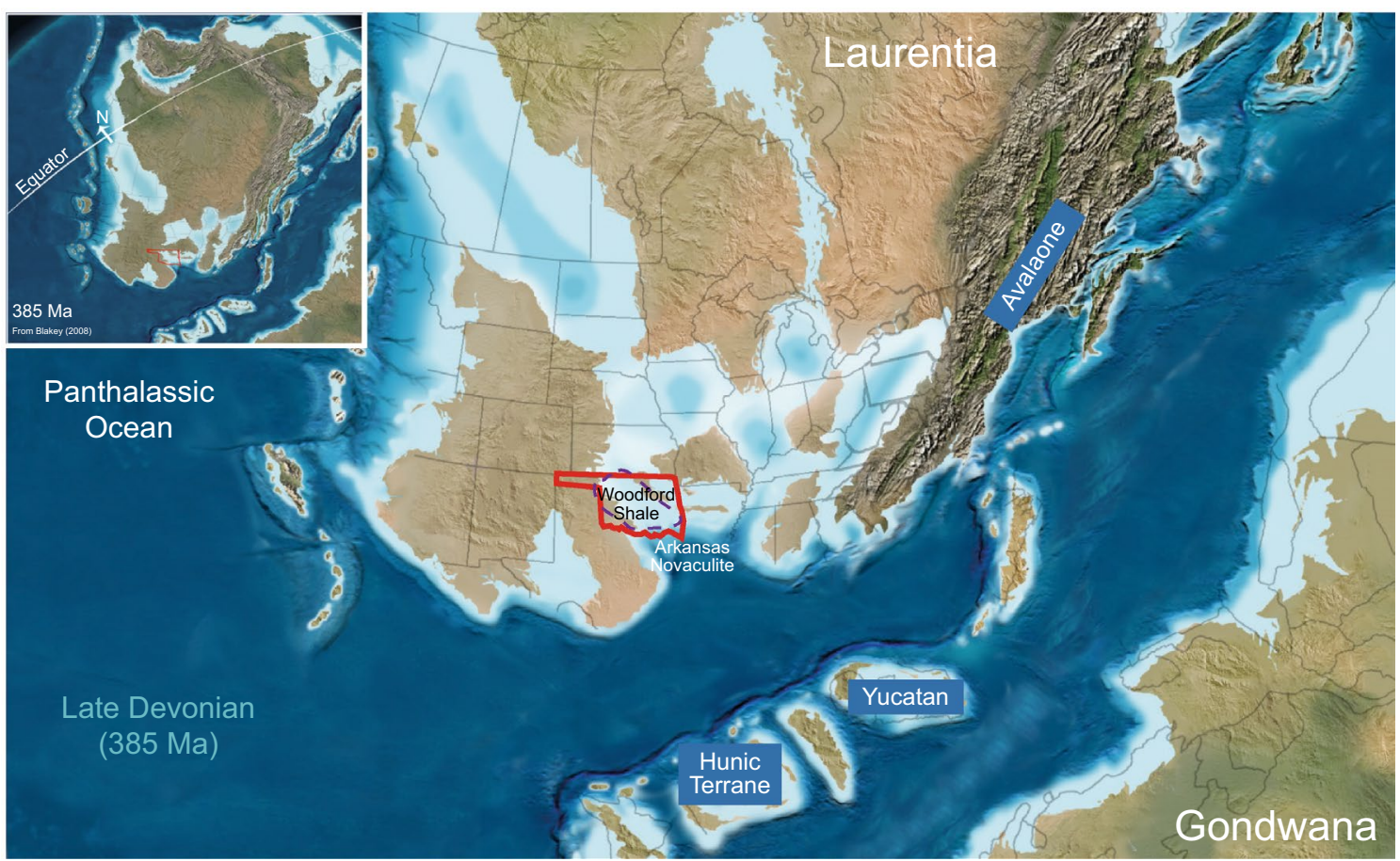

Fig. 5 Late Devonian (385 Ma) paleogeography map of North America (the ancient Oklahoma Basin is outlined by purple dots and Oklahoma by the red solid line). Modified from Blakey (2013)

is generating a greater amount of aromatics and resins than aliphatic compounds, which leads to the decrease in formation resistivity.

In the resistivity versus $R_{\mathrm{o}}$ diagram, the data points in the high-maturity area (beyond oil peak when $R_{\mathrm{o}}$ is greater than $0.85 \%$ ) are distinctly clustered into two groups and a good negative linear relationship between formation resistivity and $R_{\mathrm{o}}$ values was displayed in each group (Fig. 4). By displaying the samples' location of three groups onto the Anadarko Basin structural province map, the wells of group 3 samples were shown to be adjacent to the depocenter (Fig. 1), where type II marine shale was deposited dominantly. The wells of group 2 samples approach the basin flank (Fig. 1), where type III terrestrial organic matter get a greater chance to be received. The Late Devonian (385 Ma) paleogeography map of the study area (Fig. 5) shows that the Woodford Shale was getting started to deposit in the ancient Oklahoma basin, which was originally derived from a failed rift formed back to Precambrian. During Late Devonian, it was a restricted basin within the passive margin (Johnson 1989; Northcutt et al. 2001; Miall 2008). The Anadarko Basin flank, compared to the Anadarko Basin depocenter, was more likely to receive fluvial terrestrial organic matters from the paleohighs from northeast (Blakey 2013; Blakey and Ranney 2018). Further investigating the resistivity versus $R_{\mathrm{o}}$ diagram (Fig. 4), at the same maturity level, the data point of group 3 is less conductive than that of group 2, probably attributed to less aromatics/resins generated by group 3 type II marine kerogens than group 2 ones which contain a greater amount of type III terrestrial kerogens, resulting in more structural kerogens (producing a greater amount of aromatics/resins). Passey et al. (2010) found a similar phenomenon that resistivity decreases as source rock becomes mature as well, especially when $R_{\mathrm{o}}$ goes beyond $3.0 \%$. Passey et al. (2010) proposed an interpretation that perhaps the carbon in the organic matter is recrystallizing to the mineral graphite, which is electrically conductive. However, previous studies indicate that pure mineral graphite is not present in abundance at these thermal maturities. Thus, it is likely that a precursor to graphite is forming. It is sufficient to state that in extremely high-maturity organicrich rocks $\left(R_{\mathrm{o}}>3\right)$, the rock may be much more electrically conductive due to other mineral phases being present rather than solely formation water, clay and pyrite (as usually considered) (Passey et al., 2010).

\section{Conclusions}

As a famous traditional highly organic-rich hydrocarbon source rock, the Devonian Woodford Shale in the Anadarko Basin is used to delineate the relationship between wireline $\log$ responses and thermal maturity. Accurate values of vitrinite reflectance $\left(R_{\mathrm{o}}\right)$ present in the Woodford Shale 
penetrated by 52 control wells were measured directly to obtain an average $R_{\mathrm{o}}$ value of the middle Woodford member, which is the most organic-rich member of Woodford. The geometric average number of ILD log readings of the corresponding middle Woodford member was used as its formation resistivity. These vitrinite reflectance values, when plotted against borehole resistivity for the middle member of the Woodford Shale in the wells, display a rarely reported finding that an increase in $R_{\mathrm{o}}$ values (source rock maturity scale) is positively related to increased resistivity in $R_{\mathrm{o}}$ range of $0.60 \%-0.90 \%$ and decreased resistivity in $R_{\mathrm{o}}$ range of $0.90 \%-2.00 \%$. This phenomenon may be attributed to that aromatic and resin compounds containing conjugated pi bonds generated within source rocks are more electrically conductive than aliphatic compounds. And aromatic and resin fractions were generated more than aliphatic fraction when source rock maturity further increases beyond oil peak. The finding of the relationship between deep resistivity and $R_{\mathrm{o}}$ may re-investigate the previously found linear relationship between source rock formation and unconventional play exploration.

Acknowledgements We would like to thank ConocoPhillips for providing the cores and logs to carry out the study. Their generous contribution has made this study possible. The work was funded by the Foundation of State Key Laboratory of Petroleum Resources and Prospecting, China University of Petroleum, Beijing (No. PRP/open-1605), and was partly supported by the Open Fund of Key Laboratory of Exploration Technologies for Oil and Gas Resources (Yangtze University), Ministry of Education (No. K2017-18) and Tight Oil Enrichment and Key Exploration and Development Technology Project of National Science and Technology Major Project (Nos. 2016ZX05046-002 and 2016ZX05047-005).

Open Access This article is distributed under the terms of the Creative Commons Attribution 4.0 International License (http://creativeco mmons.org/licenses/by/4.0/), which permits unrestricted use, distribution, and reproduction in any medium, provided you give appropriate credit to the original author(s) and the source, provide a link to the Creative Commons license, and indicate if changes were made.

\section{References}

Amsden TW. Silurian and Devonian strata in Oklahoma: symposiumSilurian-Devonian rocks of Oklahoma and environs. Tulsa Geol Soc Dig. 1967;35:25-34.

Amsden TW. Hunton Group (Late Ordovician, Silurian, and Early Devonian) in the Anadarko basin of Oklahoma. Okla Geol Surv Bull. 1975;121:1-214.

Archie GE. The electrical resistivity log as an aid in determining some reservoir characteristics. Trans AIME. 1942;146(1):54-62. https ://doi.org/10.2118/942054-G.

Burruss RC, Hatch JR. Geochemistry of oils and hydrocarbon source rocks, greater Anadarko basin: evidence for multiple sources of oils and long-distance oil migration. In: Johnson KS, editors. Anadarko basin symposium, 1988: Oklahoma geological survey circular, vol. 90; 1989. p. 53-64.
Blakey RC. Gondwana paleogeography from assembly to breakup-a 500 million year odyssey. In: Fielding CR, Frank TD, Isbell JL, editors. Resolving the Late Paleozoic Ice Age in time and space: Geological Society of America, Special Paper 441; 2008. p. 1-28.

Blakey RC. Using paleogeographic maps to portray Phanerozoic geologic and paleotectonic history of western North America. AAPG Search and Discovery. 2013; Article \#30267, 61 slides. http:// www.searchanddiscovery.com/pdfz/documents/2013/30267blake y/ndx_blakey.pdf.html.

Blakey RC, Ranney WD. Ancient landscapes of western North America: a geologic history with paleogeographic maps. 1st ed. Berlin: Springer; 2018. https://doi.org/10.1007/978-3-319-59636-5.

Cardott BJ. Determining the thermal maturity level at which oil can be economically produced in the Woodford Shale: Woodford Oil Congress, Oklahoma City; 2014. http://www.ogs.ou.edu/fossilfuel s/pdf/2014CardottOilCong.pdf.

Comer JB. Stratigraphic analysis of the Upper Devonian Woodford Formation, Permian basin, West Texas and southeastern New Mexico. Report of investigations, vol. 201. Austin: Bureau of Economic Geology; 1991a. p. 1-63.

Comer JB. Organic geochemistry and paleogeography of Upper Devonian Formations in Oklahoma and western Arkansas. In: Johnson KS, Cardott BJ, editors. Source rocks in the southern Midcontinent, 1990 symposium: Oklahoma geological survey circular, vol. 93; 1991b. p. 70-93.

Comer JB. Facies distribution and hydrocarbon production potential of Woodford Shale in the southern Midcontinent. In: Cardott BJ, editor. Unconventional energy resources in the southern Midcontinent, 2004 symposium: Oklahoma geological survey circular, vol. 110; 2005. p. 51-62.

Comer JB. Woodford Shale in southern Midcontinent, USA-transgressive system tract marine source rocks on an arid passive continental margin with persistent oceanic upwelling: AAPG annual convention, San Antonio, TX; 2008, poster, 3 panels.

Comer JB, Hinch HH. Recognizing and quantifying expulsion of oil from the Woodford Formation and age-equivalent rocks in Oklahoma and Arkansas. Am Assoc Pet Geol Bull. 1987;71(7):84458. https://doi.org/10.1306/948878C5-1704-11D7-8645000102 C1865D.

Goff JC. Hydrocarbon generation and migration from Jurassic source rocks in the E. Shetland Basin and Viking Graben of the Northern North Sea. J Geol Soc. 1983;140(3):445-74. https://doi. org/10.1144/gsjgs.140.3.0445.

Haq BU, Schutter SR. A chronology of Paleozoic sea-level changes. Science. 2008;322(5898):64-8. https://doi.org/10.1126/scien ce. 1161648 .

Hester TC, Sahl HL, Schmoker JW. Cross sections based on gamma ray, density, and resistivity logs showing stratigraphic units of the Woodford Shale, Anadarko basin, Oklahoma: U.S. geological survey miscellaneous field studies map MF-2054; 1988, 2 sheets.

Hester TC, Schmoker JW, Sahl HL. Log-derived regional source-rock characteristics of the Woodford Shale, Anadarko basin, Oklahoma. U.S. Geol Surv Bull 1866-D. 1990. https://doi.org/10.3133/ b1866d.

Jarvie DM. Worldwide Shale resource plays and potential. AAPG Search and Discovery. 2011. Article \#90104. www.searchandd iscovery.com/documents/2011/80144jarvie/ndx_jarvie.pdf.

Johnson KS. Geological evolution of the Anadarko basin: Anadarko basin symposium, 1988. Oklahoma geological survey circular, vol. 90; 1989. p. 3-12.

Jones PJ, Philp RP. Oils and source rocks from Pauls Valley, Anadarko basin, Oklahoma, U.S.A. Appl Geochem. 1990;5(4):429-48. https ://doi.org/10.1016/0883-2927(90)90019-2.

Kim D, Philp RP. Extended tricyclic terpanes in Mississippian rocks from the Anadarko basin, Oklahoma. In: Johnson KS, editor. Silurian, Devonian, and Mississippian geology and petroleum in the 
southern Midcontinent, 1999 symposium: OGS circular, vol. 105; 2000, p. 109-27.

Kirkland DW, Denison RE, Summers DM and Gormly JR. Geology and organic geochemistry of the Woodford Shale in the Criner Hills and western Arbuckle Mountains, In: Johnson KS, and Cardott BJ, editor. Source rocks in the southern Mid-continent, 1990 symposium: OGS Circular 93; 1993. p. 38-69.

Kvale EP, Bynum J. Regional upwelling during Late Devonian Woodford deposition in Oklahoma and its influence on hydrocarbon production and well completion. AAPG Search and Discovery. 2014; Article \#80410. www.searchanddiscovery.com/docum ents/2014/80410kvale/ndx_kvale.pdf.

Lockridge JP, Scholle PA. Niobrara gas in eastern Colorado and northwestern Kansas. In: Pruit JD, Coffin PE, editors. Energy resources of the Denver basin. Denver, CO: Rocky Mountain Association of Geologists; 1978. p. 35-49.

Loucks RG, Ruppel SC. Mississippian Barnett Shale: lithofacies and depositional setting of a deep-water shale gas succession in the Fort Worth Basin, Texas. AAPG Bull. 2007;91(4):579-601. https ://doi.org/10.1306/11020606059.

Meissner FF. Petroleum geology of the Bakken Formation Williston basin, North Dakota and Montana, it? In: Williston basin symposium. Billings: Montana Geological Society; 1978. p. 207-27.

Meyer BL, Nederlof MH. Identification of source rocks on wireline logs by density/resistivity and interval velocity/resistivity cross-plots. AAPG Bull. 1986;68(2):121-9. https://doi.org/10.2307/1162357.

Miall AD. The southern midcontinent, Permian Basin, and Ouachitas. In: The sedimentary basins of the United States and Canada, vol. 5; 2008. p. 297-327. https://doi.org/10.1016/s1874 -5997(08)00008-7.

Miceli RA. Geochemical characterization of the Woodford Shale, central and southeastern Oklahoma. Unpublished M.S. thesis, University of Oklahoma, Norman, OK; 2010.

Miceli RA, Philp RP. Organic geochemistry of the Woodford Shale, southeastern Oklahoma: how variable can shales be? Am Assoc Pet Geol Bull. 2012;96(3):493-517. https://doi.org/10.1306/08101 110194.

Northcutt RA, Johnson KS. and Hinshaw GC. Geology and petroleum reservoirs in Silurian, Devonian, and Mississippian rocks in Oklahoma: In Johnson KS, editor. Silurian, Devonian, and Mississippian geology and petroleum in the southern Midcontinent, 1999 symposium. Oklahoma Geological Survey Circular, vol. 105; 2001. p. 1-29.

Passey QR, Dahlberg KE, Sullivan KB, Yin H, Brackett RA, Xiao YH, Guzmán-Garcia AG. Petrophysical evaluation of hydrocarbon pore-thickness in thinly bedded clastic reservoirs. AAPG Arch Ser. 2006;1:1-210. https://doi.org/10.1306/A11157.

Passey QR, Bohacs K, Esch WL, Klimentidis R, Sinha S. From oilprone source rock to gas-producing shale reservoir-geologic and petrophysical characterization of unconventional shale gas reservoirs. SPE-131350-MS. Society of Petroleum Engineers; 2010. https://doi.org/10.2118/131350-ms.

Pepper AS, Corvi PJ. Simple kinetic models of petroleum formation. Part I: oil and gas generation from kerogen. Mar Pet Geol. 1995;12(3):291-319.
Philp RP, Jones JP, Lin LH, Michael GE, Lewis CA. An organic geochemical study of oils, source rocks, and tar sands in the Ardmore and Anadarko basins. In: Johnson KS, editor. Anadarko basin symposium, 1988. oklahoma geological survey circular, vol. 90; 1989. p. 65-76.

Schmoker JW, Hester TC. Regional trends of sandstone porosity versus vitrinite reflectance - A preliminary framework, in Nuccio VF and Barker CE. eds., Applications of thermal maturity studies to energy exploration: Denver, Colo., Rocky Mountain Section, Society of Economic Paleontologists and Mineralogists. p. 53-60.

Singh P. Lithofacies and sequence stratigraphic framework of the Barnett Shale, Northeast Texas. Unpublished Ph.D. dissertation, University of Oklahoma, Norman, OK; 2008.

Slatt RM, Singh P, Philp RP, Marfurt KJ, Abousleiman Y, O'Brien NR. Workflow for stratigraphic characterization of unconventional gas shales. In: 2008 Society of Petroleum Engineers shale gas production conference, Fort Worth, Texas, SPE-119891-MS. 2009a. https ://doi.org/10.2118/119891-ms.

Slatt RM, Singh P, Borges G, Perez R, Portas R, Vallejo J, Ammerman M, Coffey W, Eslinger E. Reservoir characterization of unconventional gas shales: example from the Barnett Shale, Texas, USA. AAPG Search and Discovery. 2009b; Article \#30075. http://www. searchanddiscovery.com/documents/2009/30075slatt/ndx_slatt .pdf.

Smagala TM, Brown CA, Nydegger GL. Log-derived indicator of thermal maturity, Niobrara Formation, Denver Basin, Colorado, Nebraska, Wyoming. In: Woodward J, Meissner FF, Clayton JL, editors. Hydrocarbon source rocks of the greater Rocky Mountain region. Denver, CO: Rocky Mountain Association of Geologists; 1984. p. 355-63.

Wang HD. A geochemical study of potential source rocks and crude oils in the Anadarko basin, Oklahoma. Unpublished Ph.D. dissertation, University of Oklahoma, Norman, OK; 1993.

Wang T. An organic geochemical study of Woodford Shale and Woodford-Mississippian tight oil from Central Oklahoma. Ph.D. dissertation of University of Oklahoma, Norman, Oklahoma; 2016.

Wang HD, Philp RP. Geochemical study of potential source rocks and crude oils in the Anadarko Basin, Oklahoma. Am Assoc Pet Geol Bull. 1997;81(2):249-75. https://doi.org/10.1306/522B42FD1727-11D7-8645000102C1865D.

Wang T, Philp RP. Oil families and inferred source rocks of the Woodford/Mississippian tight oil play in North-Central Oklahoma. AAPG Bull. 2019;103(4):871-903. https://doi.org/10.1306/09181 818049.

Waxman MH, Smits LJM. Electrical conductivities in oil-bearing Shaly Sands. SPE J. 1968;8(2):107-22. https://doi.org/10.2118/1863-A.

Worthington PF. Evolution of Shaly Sand concepts in reservoir evaluation. Log Anal. 1985;26(1):23-40.

Zhao H, Curtis B, Givens N. Thermal maturity of the Barnett Shale determined from well-log analysis. AAPG Bull. 2007;91(4):535_ 49. https://doi.org/10.1306/10270606060. 